Vorstandsmitglied und Präsident der Deutschen Dermatologischen Gesellschaft hat er in Zeiten des gesundheitspolitischen Umbruchs mit großem Geschick die Interessen der Dermatologie und Allergologie vertreten. Für seine großen Verdienste um die Deutsche Dermatologie wurde ihm 2003 als Erstem die Braun-Falco-Plakette verliehen.

Beispielhafte Einsatzbereitschaft zeigte Schöpf auch in der universitären Selbstverwaltung. So war er zweimal Dekan, in Heidelberg und in Freiburg, und Prorektor der Universität Freiburg. Die Förderung des dermatologischen und allergologischen Nachwuchses war ihm stets wichtig. Aus seiner Schule kommen weit über 100 Fachärztinnen und Fachärzte, mehr als 20 ausländische Dermatologen und last, but not least 18 Habilitanten.

Auch nach dem Ausscheiden von Erwin Schöpf als Direktor der Univer-
sitäts-Hautklinik Freiburg lebt eine starke wissenschaftliche Tradition dort weiter. Die von ihm mit aufgebaute Forschergruppe für Allergologie, das Dokumentationszentrum schwerer Hautkrankheiten sowie die neu etablierten Forschergruppen für Grundlagen und Mechanismen von Genodermatosen und Autoimmunerkrankungen arbeiten mit Elan und Erfolg weiter. Erwin Schöpf verfolgt diese Themen regelmäßig als aktiver Seminargast und Diskussionsteilnehmer.

\section{Humanist mit Savoir-vivre}

Diese Laudatio wäre unvollständig wenn neben dem Arzt, Forscher und berufsund wissenschaftspolitischen Strategen nicht auch der Mensch Erwin Schöpf mit seiner breiten humanistischen Bildung und selbst in schwierigen Situationen immer positiven Grundhaltung gewürdigt würde. Seine Persönlichkeit ist gekennzeichnet durch ein großes Gespür für Qualität und das rechte Maß, die stete Aufgeschlossenheit gegenüber Neuem und eine hohe Sensibilität. Diese Eigenschaften erstrecken sich auch auf Kunst, Kultur und Savoir-vivre. Sie werden von seiner feinsinnigen Frau selbst eine Ärztin und Künstlerin - und seiner Tochter, die ebenfalls Ärztin ist, sowie deren Familie geteilt. Schüler, Kollegen, Mitarbeiter, Freunde und die Autoren gratulieren herzlich und wünschen Erwin Schöpf, dass er die Früchte seines Werks viele Jahre genießen kann.

Prof. Dr. Jan C. Simon, Leipzig; Prof. Dr. Leena Bruckner-Tuderman, Freiburg

\title{
Klosterfrau Award for Research of Airway Diseases in Childhood 2011
}

Airway diseases are the most common diseases in childhood and are great clinical scientific and therapeutic challenges in pediatrics. Their incidence is very high in all countries of the world. Children suffering from many of these diseases as well as their parents have to go through a painful path of psychic stress and disappointments. Scientists around the world are joining efforts to understand the etiology of these diseases, to improve its therapy and to develop new and more effective therapeutic concepts.

The "Klosterfrau Research-Award for Airway Diseases in Childhood" has been installed primarily as an annual prize for childhood asthma, but will now be awarded to researchers in basic science, pneumology and pediatrics whose work is orientated towards a better understanding of airway diseases in children, especially those suffering from bronchial asthma, congenital disorders of the airway tract as well as primary diseases of the lung parenchyma.

The prize is endowed with $30.000 €$ and will be given to one person or team. $10,000 €$ of this sum are at the individual disposal of the prize winner (winning team), whereas $€ 20,000$ have to be spent for further research of the winner or his team.

\section{Guidelines}

1. The applicant must be under the age of 40 years.

2. Each application must be by a single applicant.

3. The work must be from the past two years.

4. The work may be clinical or basic research in asthma, by a researcher whose major clinical training and work has been in pediatrics.

5. Majority of the research work should have been performed by the applicant.
6. Application should contain a short statement of the head of the research group that he/she (the group) supports the application.

7. The applicant must submit a short curriculum vitae and a list of his/her publications.

8. The applicant must submit a summary of his/her work, with an indication of its clinical relevance to childhood asthma and which questions arising from the work need to be answered in the future.

9. Reviews of the literature will not be accepted.

10. Papers or PhD thesis should be presented as a supplement to the application.

11. Universal application form should be used. It must contain: - Title and full address

- Manuscript(s)

- A summary of the work

- Curriculum vitae and list of publications

- Explanations by the applicant and the head of the research group that the applicant has performed majority of the research work.

Selection of the award recipient(s) will be made of an international scientific board, made up of six internationally recognized senior scientists. Please send your application (by email only) by December 16th, 2011, at the latest to the Chairman of the International Scientific Board

\section{Prof. Dr. Dr. Dietrich Reinhardt}

Dr. von Haunersches Kinderspital, University of Munich (LMU)

- Klosterfrau Preis -

Lindwurmstraße 4, 80337 München

E-mail: dietrich.reinhardt@med.uni-muenchen.de 